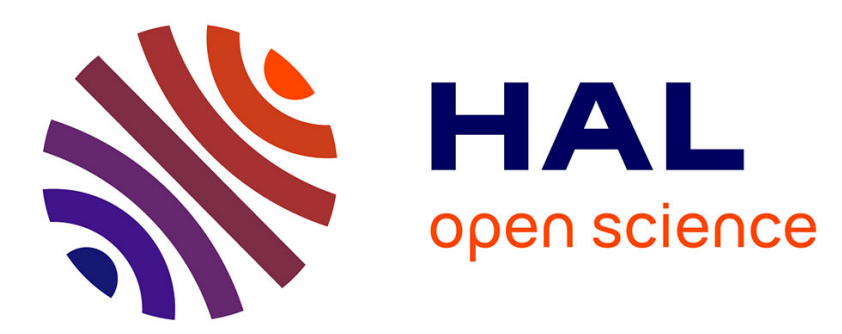

\title{
Belts and Pins as Gendered Elements of Clothing in Third and Second millennia Mesopotamia
}

Cécile Michel

\section{To cite this version:}

Cécile Michel. Belts and Pins as Gendered Elements of Clothing in Third and Second millennia Mesopotamia. Harlow, Mary; Michel, Cécile; Quillien, Louise. Textiles and Gender in Antiquity from the Orient to the Mediterranean, Bloomsbury, pp.179-192, 2020, 9781350141490. hal-03088839

\section{HAL Id: hal-03088839 \\ https://hal.science/hal-03088839}

Submitted on 4 Jan 2021

HAL is a multi-disciplinary open access archive for the deposit and dissemination of scientific research documents, whether they are published or not. The documents may come from teaching and research institutions in France or abroad, or from public or private research centers.
L'archive ouverte pluridisciplinaire HAL, est destinée au dépôt et à la diffusion de documents scientifiques de niveau recherche, publiés ou non, émanant des établissements d'enseignement et de recherche français ou étrangers, des laboratoires publics ou privés. 


\title{
CHAPTER 13
}

\author{
BELTS AND PINS AS GENDERED ELEMENTS \\ OF CLOTHING IN THIRD AND SECOND \\ MILLENNIA MESOPOTAMIA
}

\section{Cécile Michel}

Cuneiform texts include many words linked to textile terminology which highlight varieties of materials, weaving techniques and regional peculiarities. During the third millennium and the first half of the second millennia BCE, forms of clothing were rather simple in the Near East, including tunics and wrap around garments for both men and women. Texts from this period do not make clear gender distinctions, presumably because tailored garments are still rare and reserved to the elite. The iconography, often subject to conventions in representations, gives an idea of the shape of clothing at different times. But the two corpus, texts and images, do not necessarily match. Using both textual and visual evidences for the third and first half of the second millennium BCE, this chapter intends to show that even if men and women used to wear the same types of clothes, they arranged their garments around their body differently, using distinctive elements to fix them: belts for men and pins for women.

Key words: Cuneiform, Mesopotamia, Early and Middle Bronze Age, gender, garments, belts, pins.

Dress, besides its evident practical use, is viewed, since the seminal reflections of Roland Barthes (1957), as a language of the body which carries various aspects of personal identity. He suggested that scholars should analyse "the tendency of any body coverage to be part of a formal organised, normative system established by society' (Barthes 1957: 433-44). ${ }^{i}$ Moreover, dress has a dynamic role which modifies the body and participates to the construction of identity, may it be social, cultural, or linked to the gender (Cifarelli and Gawlinski 2017: ix-xvi).

In early Mesopotamia, woven garments are attested in the archaic texts of Uruk (fig. 13.1, late fourth millennium BCE) and are depicted on statuary and reliefs, as for example on the Uruk vase. In all instances, clothes dress up dignitaries, kings and priests, goddess or priestesses, while the servants, the men who bring the offerings appear naked (Breniquet 2013: 10). Thus, initially, garments were linked to social status.

In Akkadian Literature, clothes are also described for their cultural identity and social function. In the Epic of Gilgameš, Šamhat, the harlot, takes off her clothes to seduce Enkidu, and Enkidu himself is integrated in the civilized world by eating bread, drinking beer, wearing a garment, and having a sexual encounter with the prostitute (Bahrani 2001: 51; Georges 2018). As Anne Caroline Rendu Loisel reminds us, 'whether they are women, men, gods or goddesses, individuals use their clothes in a kind of rhetorical language to express their own identity and social rank' (Rendu Loisel in press).

The terminology of garments is abundant; beyond social and gender distinctions, it highlights varieties of materials, weaving techniques, and regional peculiarities. The iconography, often subject to conventions in representations, gives an idea of the shape of clothing at different times. However, the two corpuses, texts and images, do not necessarily match as they do not speak the same language (Harlow and Michel in press).

During the third millennium and the first half of the second millennium BCE, the forms of clothing were rather simple in the Near East, consisting primarily of tunics and wrap around garments for both men and women. According to textual documentation, ready-to-wear garments seems to appear at the beginning of the second millennium at Mari, where the royal archives evoke clothes often reserved for the king and its court, with the addition of pockets, sleeves and embroidery (Durand 2009). At the same 
time, however, contemporary private archives belonging to Assyrian merchants mainly deal with various pieces of fabric which are ungendered (Michel and Veenhof 2010). Cuneiform texts, thus, do not make clear gender distinctions concerning the clothes worn by men and women. However, the iconography suggests that men and women were arranging their garments around their body in different manners.

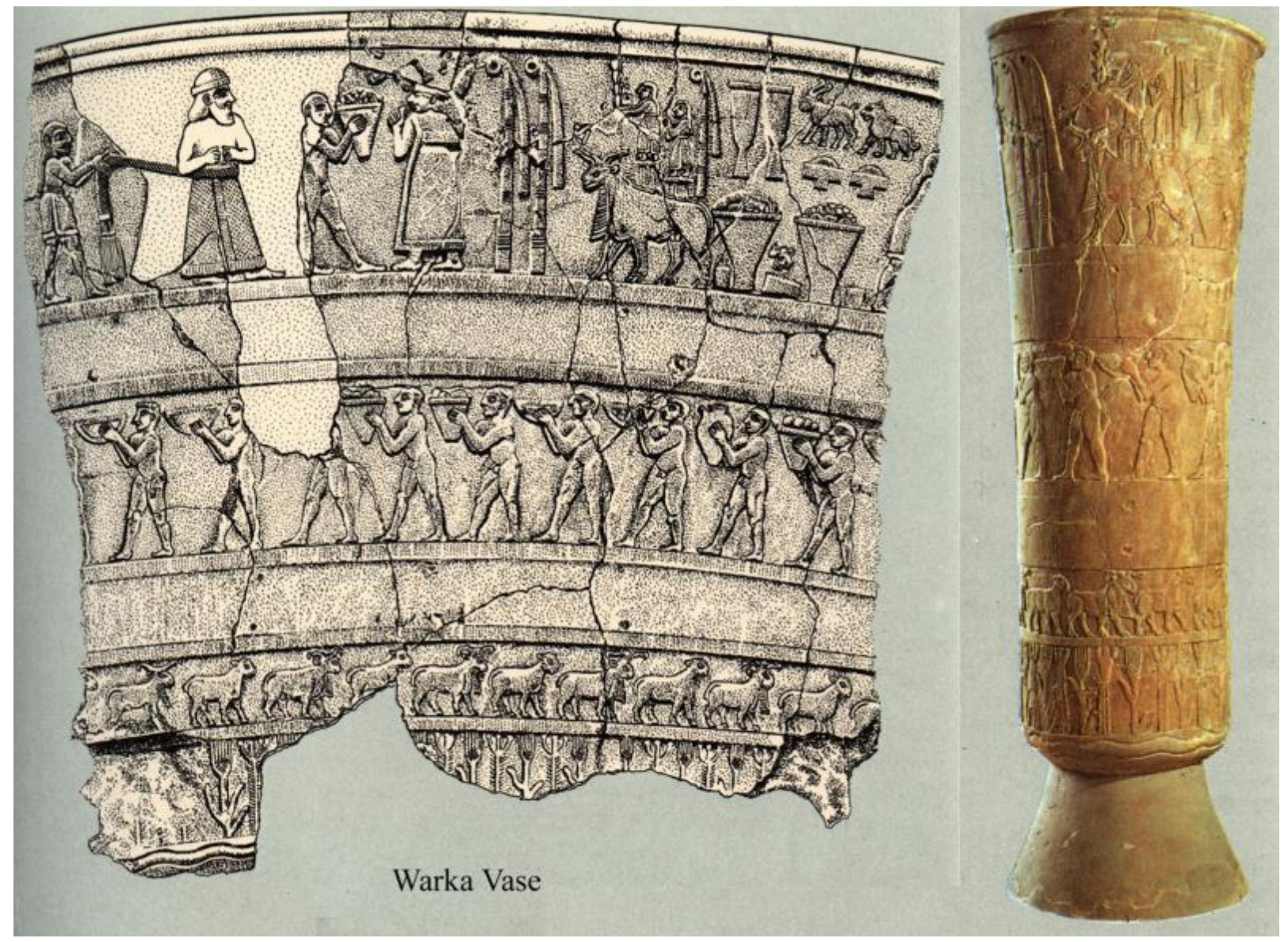

Figure 13.1. The Uruk vase and its restitution, ca. 3000 BCE, The Iraq Museum in Baghdad. Creative commons image: https://en.wikipedia.org/wiki/File:Warka_Vase1.jpg

Based on literary texts, administrative and private archives as well as on visual representations dating to the second half of the third millennium and first half of the second millennium BCE, this chapter aims to identify elements of Mesopotamian costume that are gender distinctive. Evocations of cross-dressing will be explored in order to determine whether elements of clothing may be linked more specifically to one or the other gender. The most representative elements of femininity and of masculinity, respectively toggle pins and belts will then be analysed in order to understand their symbolic meaning beyond being linked to one or the other gender.

\subsection{Dressed like a Man, Dressed like a Woman}

Contemporaneous literary texts do make a distinction between male and female clothes, suggesting that when meeting someone, it was important to have no doubt concerning this person's gender. When a woman was dressed as 'masculine' or a man as 'effeminate', they were considered as marginal and unable to act in the appropriate cultural and gendered ways. Sumerian and Akkadian compositions 
linked to the cult of the goddess Inana/Ištar deal with cross-dressing and cross-gender activities. For example, a Sumerian hymn to Inana for king Išme-Dagan (Hymn K), which dates to the eighteenth century BCE, recalls that the goddess had the power to change men into women and vice versa:ii

Inana was entrusted by Enlil and Ninlil with the capacity to (...) to turn a man into a woman and a woman into a man, to change one into the other, to make young women dress as men on their right side, to make young men dress as women on their left side.

Representations of the third and early second millennia BCE are not so systematic; if this lateralisation of the clothing matches with some iconographic corpuses concerning women (Parrot 1981: nos.139, 143, 228; Couturaud in this volume), it is not consistent: women and men may have both their right shoulder uncovered (Couturaud 2019: no. 192 for a woman, nos. 335-336, 354 for men; see also Parrot 1981: no. 240, 248), or women have, in many cases, both of their shoulders covered by a shawl. The twenty-second century statue of a princess named la 'femme à l'écharpe' preserved in the Louvre Museum represents a very fine example (Spycket 1981: pl. 136a-b; voir aussi Parrot 1981: no. 225, 232). iii

An Akkadian hymn to Ištar, known by a copy of the late Old Babylonian period or early Middle Babylonian period, gives more details:

The (usual) behaviour is turned up-side-down (...) You make men obey (the rules of) garments (and) wigs. At night, the women are touched. They are untidy regarding the hair-locks. (...) Verily the woman, like a man, her dress is untidy. (...) The men are endowed with combs like a woman. Their cloth is multi-coloured. Their (head) is covered with multi-coloured (cloths).

Streck and Wasserman 2018: 6, col. ii 1, 3-4, 11, 19-20

The men are thus endowed with specific female attributes and vice-versa, women receive male specific attributes and their dress is untidy. If we limit these attributes to clothes, female garments include hairpins, multi-coloured cloth and multi-coloured headgear; no specific clothes are mentioned linked to men, but by contrast, we can imagine that they wear unicolor or white garments (as in the text studied by Abrahami and Lion in this volume).

Female headgear, in the context of cross-dressing, is also attested in the Hittite 'Oath of the first soldier'. In this text, any soldier who breaks the oath it threatened with ridicule by being turned into a woman. This transformation involves among other things, clothing: He who transgresses these oaths and takes part in evil against the king, queen and princess may these oath deities make (that) man (into) a woman. May they make his troops women. Let them dress them as women. Let them put a headscarf on them (Collins 1997: 1. 66). The text mentions the dresses of a woman without any specification about their shape, material, technique, size or colour. The only specificity of the women's clothes here is a 'headscarf'. A question that has been the subject of much debate concerns what women wore or did not wear on their heads. 
Several second millennium texts mention that some women wore a headscarf in certain circumstances. ${ }^{\text {iv }}$ In the nineteenth century Old Assyrian sources, during the marriage ceremony, the bride's head was covered by her father or a male relative, apparently so that the groom could uncover her:

As to my bad niece whom they brought here at my written request, I will also clear away her additional affair and I will do my best so that there will be no disputes behind my back. I am waiting for Lalia, and at the arrival of Lalia, I will place the scarf over the head of the girl and (then) I will undertake my journey (Michel 2020: no. 16).

In this letter, the bride is married off by her uncle who intends to cover her head with a scarf during the marriage ceremony. This short rite, consisting of 'placing the headscarf over the girl's head,' presumably symbolized the woman's change of status; it need not imply that every married woman, at the beginning of the second millennium BCE, had to wear a headscarf daily. This symbolic act is referred to by the author of the nineteenth century Old Assyrian Sargon Legend when the king explains that he covered the heads of the people of Alašiya, the modern island of Cyprus, 'like if they were women' ( $\mathrm{Kt} \mathrm{j} / \mathrm{k}$ 97:5355, Günbatt1 1997; Tanaka 2014: 148; Kouwenberg 2015: 166).

The same tradition is attested by the eighteenth century Mari royal archives. During the marriage of king Zimrī-Lîm with the princess Šibtu from Yamhad, an emissary came to negotiate the project with the bride's family (Durand 1998: 95-117; Sasson 2015: 107-10). When both families agreed, the servant gave the gifts from the bridegroom's family and the bride received a headscarf.

According to the fourteenth century Middle Assyrian Laws (§40) married women covered their head, as well as unmarried women of good family. This custom was not only a gender marker, but also an external symbol for women marking their place in society. Indeed, prostitutes and slave women had to be bare headed, they were not allowed to cover their heads. If they did so, they were punished because they usurped a status that was not theirs (Roth 1996: 167-9).

Women's representation from the third and second millennia BCE - which in general concerns those belonging to the elite and to the religious sphere - show quite a variety of ways to arrange the hair and to cover or not cover the head.

A more general question concerns the wardrobe of men and women. Are they completely different or do they present some similarities? Various incursions in corpuses of texts from the first half of the second millennium, as tailored textiles were not yet common, suggest that ordinary men and women wore the same type of fabric (Durand 2009: 12-14). Texts distinguish clothes for children because of the smaller size (Michel and Veenhof 2010, 241-2, 267). Only shoes seem to have been quite systematically gender distinctive, presumably because of the different sizes of male and female feet. 


\subsection{Pins for Women}

Even if they used the same type of rectangular fabric - not taking into account the colours which are rarely specified in the analysed corpus - men and women could wrap it around their body in different fashions. To hold or fix the garment, they used accessories, and these seem to be different according to the gender of the dressed person.

Some representations and written sources from the third and second millennia show that women were using long metal toggle pins to fix their clothes around their body. As H. Klein, who identified the Akkadian word, tudittum, had already observed: 'toggle pins were exclusively attached to the clothing of female persons (...) they did not belong to the male costume' (Klein 1983: 280).

The way women used to wear these pins is exceptionally well represented on inlays also found at Mari and dating to the middle of the third millennium BCE (Couturaud 2019, 58-9, and in this volume). The three types of pins represented - short and straight worn by pairs (fig. 13.2a), curved (fig. 13.2b), long with a visible head (fig. 13.2c) - correspond to those found in excavations. Barbara Couturaud has noted that the size of the pins represented on the female costumes of Mari inlays are exaggerated perhaps to visually emphasize their importance (Couturaud 2019: 58). According to her estimations, they would reach 30 to $40 \mathrm{~cm}$, while those found in excavations measure between 15 and $25 \mathrm{~cm}$. The huge size of the pins represented on the Mari shell mosaics echoes those found in early Iron Age burials of women at Hasanlu (Iran): sixteen long pins measuring up to $37 \mathrm{~cm}$ in length were found on the bodies of eight women (Cifarelli 2017: 110).
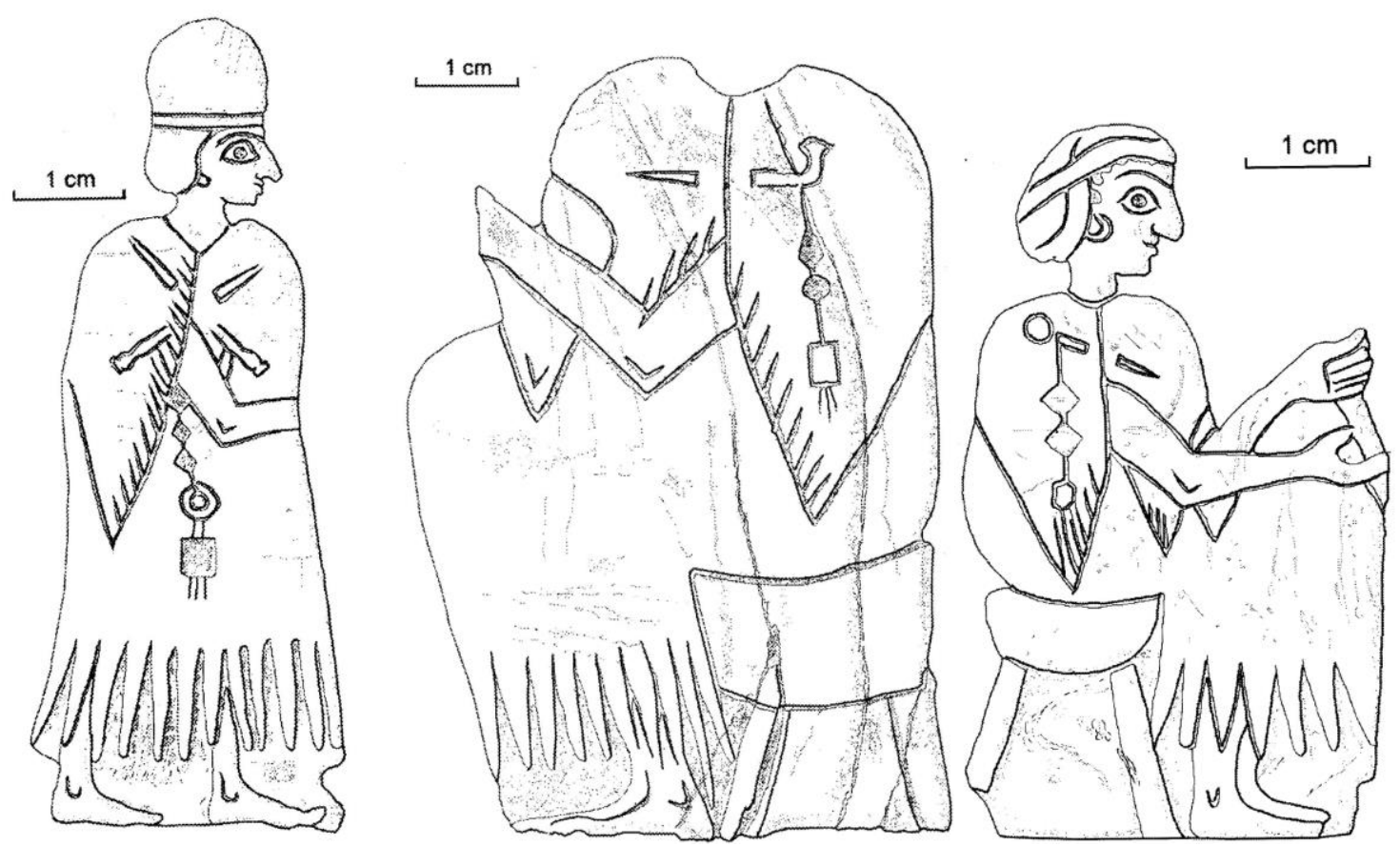

Figures 13.2a-c. Mari mosaics from the middle of the third millennium BCE presenting the three types of toggle pins and the different ways to wear them. After Couturaud 2019: nos. 522, 566 and 567, with the kind permission of the author. 
Megan Cifarelli suggested that: 'Elite women consciously embraced the wearing of dress ornaments that served as visual amplification of the closure of their garments, and the unassailability of their persons, a strategy that might have offered them protection from physical injury (Cifarelli 2017: 115).' In the Old Assyrian texts, smaller toggle pins are regularly offered to women, sometimes young women at the occasion of their marriage, as in the following text: 'a pin of 13 shekels (105g) of silver for our daughter-in-law' (TC 3, 202:15-16). ${ }^{\mathrm{v}}$

Such pins, clearly used to close the female garment, are also linked to some divorce procedures. When the divorce was pronounced to the detriment of the woman, she had to remove the pin holding her garment and leave her husband's house 'naked':

Puzur-Šamaš married Hašušārnika as amtum-wife. If Puzur-Šamaš breaks the contract and divorces her, he shall pay 1 mina of silver. If Hašušãrnika commits a misdeed, she shall leave (the house) drawing out the toggle pin (of her cloth). (Michel 2020: no. 32).

The symbolic gesture of taking out the toggle pin of the female cloth, which could be done either by the woman or her husband, meant that she abandoned all her possessions to him while leaving the house (Michel 2020: no. 31). ${ }^{\text {vi }}$ It confirms that these pins were linked to femininity and represented the most important element of the woman's clothes. And in fact, in the Old Assyrian Sargon Legend, the king, as he wanted to ridicule his enemies by treating them like women, gave toggle pins to some of them: 'He provided the Luhmians with a toggle pin' (Kt j/k 97:61-62; Kouwenberg 2015; 2017: 87, n. 25). Toggle pins are also found in the assets of a woman to be divided according to her will, together with metal cups, silver, loan contracts, textiles, and slaves; the toggle pins are for her daughter (Michel 2020: no. 61). ${ }^{\text {vii }}$

Archaeological discoveries at Kültepe show that such pins, from 6 to $16.5 \mathrm{~cm}$, often made of precious metal, gold, silver or iron, could have a decorated head including semi-precious stones as lapis lazuli or agate (fig. 13.2; Kulakoğlu and Kangal 2010: 306-11; Michel forthcoming). In the royal archives of Mari, they are often mentioned by two or a multiple of two, which suggests that they were worn in pairs, and beads or a cylinder seal could be attached to them (Arkhipov 2012: 101-2). Their weight ranged from 2 to 15 shekels in silver or gold, and from 3 shekels to more than a mina in iron; these last data would match with the extremely long - and thus heavy - pins mentioned above. ${ }^{\text {viii }}$ M. Iamoni (2012), observing the numerous toggle pins found in Syrian excavations, suggested that their use was a response to fashion and it played a role in the selection of garments.

In literary texts, toggle pins are worn by goddesses to fix their clothes, as for example in the Inana/Istar's Descent to the Netherworld, known in both Sumerian and Akkadian versions. Before going to the Netherworld, the goddess dressed herself with garments and jewels representing all her powers. But following the orders of her sister the Queen of the Netherworld, the gatekeeper explained to her that she could enter but first had to remove a piece of her clothing for each of the seven doors she passes through. When entering the fourth door, she had to take off the garment pins of her breast (Foster 2005: $500,1.51)$. We can imagine that at the same time her garment fell down. When she arrived in front of her sister, she was naked and had lost all her powers. 

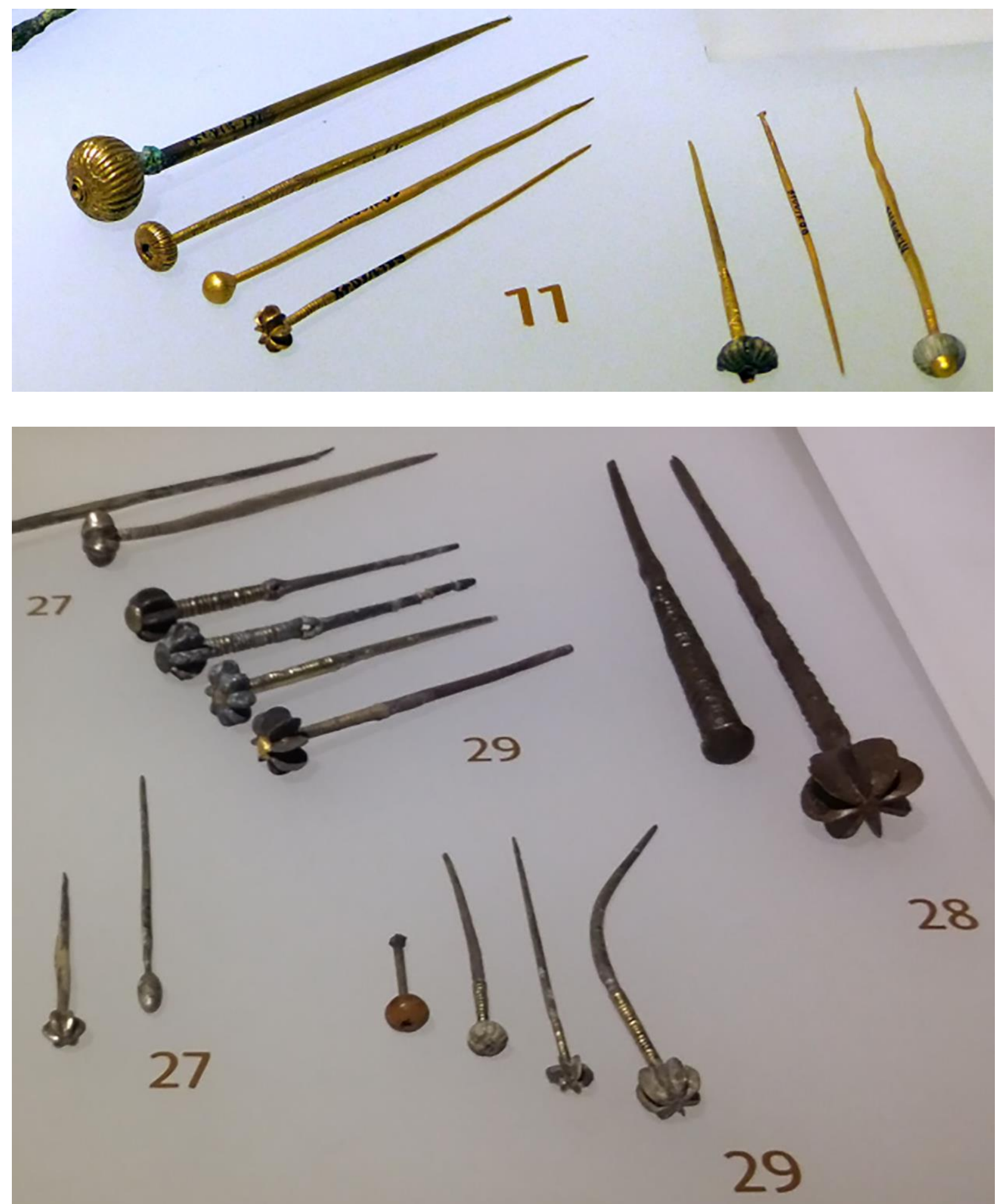

Figure 13.3a-b. a) Gold and b) silver toggle pins from Kültepe. Ankara Anadolu Medeniyetleri Müzesi. Photo: C. Michel, @Kültepe Archaeological Mission.

\subsection{Belts for Men}

If women used to attach their clothes with the help of toggle pins, what were men using to fix their garment around their body? Both textual and iconographic evidence suggest that the main accessory of men was the belt. In the Gilgameš Epic, the hero 'wrapped himself in cloaks, tied with a sash' used as a belt (Gilgameš VI:4; George 2003: 619). This belt was also very useful for holding the dagger or another 
weapon, symbols of power. Indeed, the hero invoking an image of his friend Enkidu as his most treasured possession, a trusty weapon, declared:

The axe at my side, in which my arm trusted, the sword of my belt, the shield in front of me.

(Gilgameš VIII:46-47; George 2003: 655).

So, the belt was not only an attribute of masculinity in ancient Mesopotamia, but it also represented power. This is also suggested by the Old Assyrian Sargon Legend when the king recounts his exploits:

I saw a gazelle and threw a mud brick into the river, but while I was running my belt broke, so I put a snake in its place. I ran and caught the gazelle and picked up the mud brick from the water. (Kt j/k 97:13-18, Dercksen 2005).

Sargon is seen here as a kind of superman, running very fast. While running, he was able to catch a gazelle and retrieve a mud brick from the river before it got dissolved; this looks like a triathlon competition with running, brick throwing (and retrieving), and diving. Sargon uses a snake as an item of dress, moreover as a belt, a symbol of masculinity, thus his identification as a superman who dominates the wilderness is highlighted (Tanaka 2014: 142-5).

The importance of the belt as element of masculinity is corroborated by some representations of men throughout Mesopotamian iconography: the belt of men may be highlighted or drawn with great attention. ${ }^{\text {ix }}$ First millennium reliefs and statues show men carrying their dagger hanging at their belt.

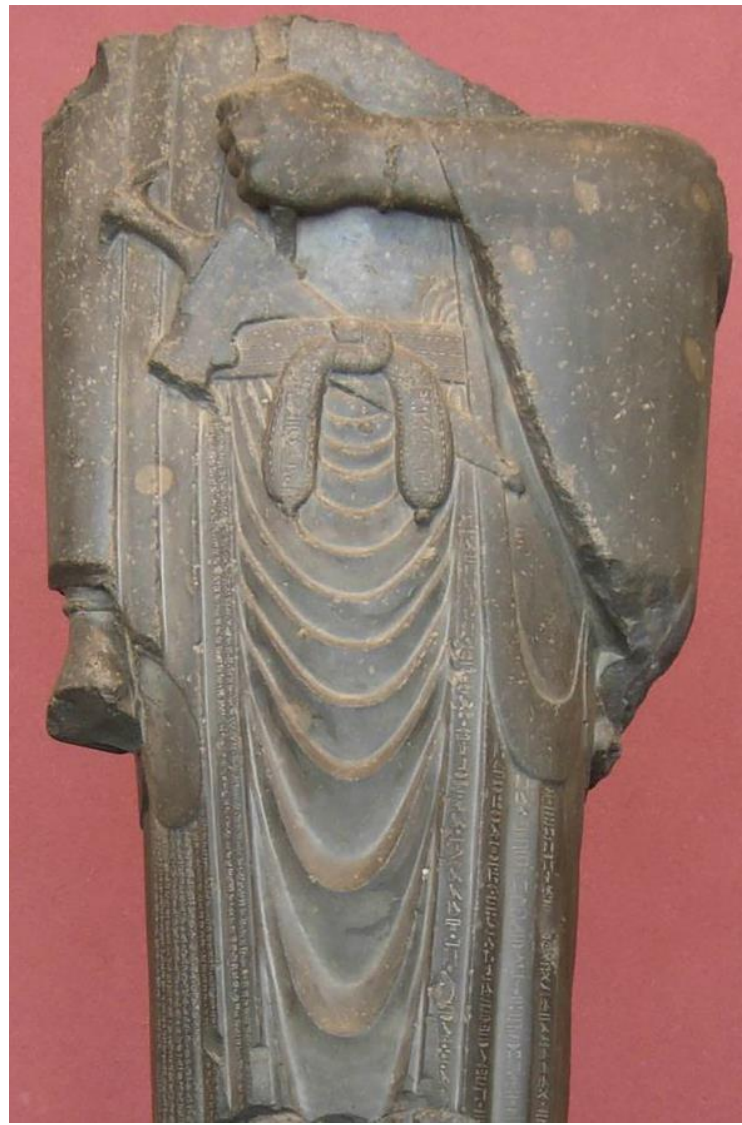

Figure 13.4. Statue of Darius the Great dating between 495 and 486 BCE, Susa. National Museum of Iran, Teheran. Creative commons image: https://commons.wikimedia.org/wiki/File:31739-Tehran_(8012461439).jpg?use$\underline{\text { lang=fr }}$ 


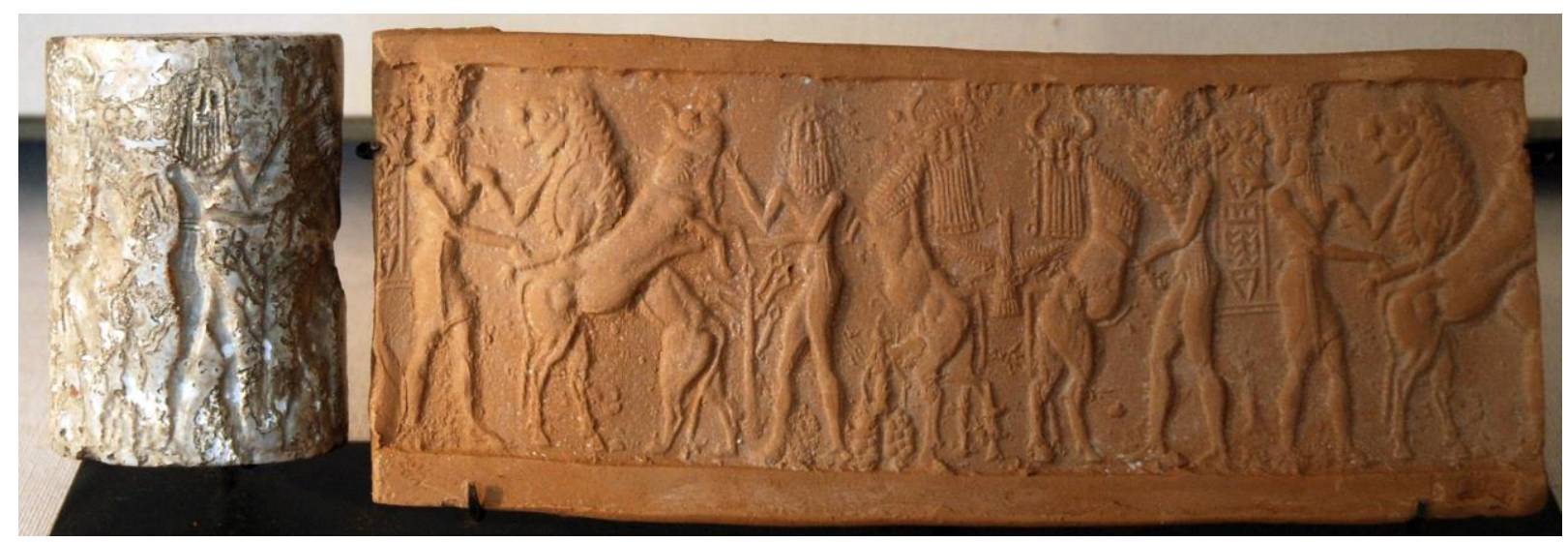

Figure 13.5. Belted nude hero on a marble cylinder seal from Tello, period of Akkade, middle of the third millennium BCE (MNB1344). Louvre Photo M. Esline, with the kind permission of the Louvre

Moreover, Z. Bahrani noted that representation of nude heroes in scenes of wrestling or mock combat were often wearing only belts (Bahrani 2001: 57-8); these could once more be seen as a symbol of power and masculinity.

Outside literary texts and iconography, the belt appears as one of the most important present to give to a man, for example in the exchange of gifts before marriage, as shown by this Old Assyrian legal text:

Pilah-Ištar summoned us (as arbitrators) against Amur-Ištar and Pilah-Ištar (said) as follows: 'You gave your word to my father. Come and marry your wife!' Amur-Ištar (answered) as follows: 'I indeed gave my word to your father, but as my in-laws you (pl.) did not give me a belt for my waist, nor did you invite my brothers. Time passed and I have grown old, so I have married another woman of Aššur. Thus, I will not marry your sister'

Michel 2020: no. 7.

The word išrum, 'belt', used in this text refers to a long piece of cloth tied at the waist (see above the sash used as a belt by Gilgameš; Michel and Veenhof 2010: 233). The Old Assyrian private sources mention two other types of belts: the šakkukum, a girdle or a belt made of metal and which could be ornamented with precious stones (Michel 2001: 72, n. a), and the musārum, perhaps also a metal belt. The offering of a belt could also be made to one's father-in-law, as in the following long list of expenses for a marriage ceremony:

When we introduced our father-in-law (into the house), I paid $2 / 3$ shekel 15 grains for a (metal musārum) belt instead of a (woollen išrum) belt; I paid $1 / 4$ shekel for a pair of (sandals with) thin straps (and) $2 / 3$ shekel and 15 grains for 3 jars (of beer). I paid $1 / 4$ shekel for meat and invited our father-in-law and his friends (...) I gave a (metal šakkukum) belt for his brother

Michel 2020: no. 14, 1. 1-6, 41-42. 
Women are regularly sending belts to their male relatives, including išrum-belts that they have presumably woven: Šarrat-Ištar sends a belt to her father and to another person (Michel 2020: no. 172:4-5), Ennum-Ištar sends to her son a single belt (Michel 2020: no. 198: 31-33, the son might have asked for more than one), Ahaha gives her brother Aššr-mūtappil a belt (Michel 2020: no. 282: 34), and Annaanna sends various goods to her husband including shoes, a musārum-belt, and two ǐšrum-belts (Michel 2020: no. 326: 6-12). All these examples come from the Old Assyrian private archives, but there are many more references throughout cuneiform sources highlighting the importance of the belt for men (see Quillien in this volume).

Interestingly, the belt had the same symbolism in ancient Greece. According to Pauline SchmidtPantel (2019), the anthropology of the use of the belt in the Greek world interrogates the porous borders between economic transaction, ritual gesture, social assignment and the construction of identity as well as the forms of power. As in Mesopotamia, in ancient Greece the belt is seen as a symbol of masculinity and power. The Roman military belt was worn around the waist of the soldier and acted as a holder for his dagger and the apron that hung from the front portion of the belt. Roman soldier's belts were broken if they were disgracefully discharged from the army, or forced to leave. They continued to proudly display their belts on funerary monuments which suggests they kept them, or they continued to have value for them if they retired as veterans (Hoss 2012).

\subsection{Conclusion}

During the third and early second millennium BCE, men and women were wearing similar garments; however, they arranged them around their body in different manners using different accessories. Both cuneiform texts and ancient Near Eastern representations suggest the existence of codes for dressing according to gender. It is therefore important to analyse these dress codes, and to see under which circumstances or on which parts of the costume these codes could meet.

In this period tailored garments were rare and presumably reserved to the elite. Textile production does not seem to have been gendered. Thus, we can imagine that what came out of workshops or private homes could be worn indiscriminately by men or women, unless the person in charge of the finishing of textiles could already offer a cut or shaped form. The terminology of garments in cuneiform sources rarely suggests a gender distinction. The difference in clothes seems to have been primarily socially and culturally important. Social status was expressed, for example, in the type of textile used, the length of the tunic, the manner in which it was decorated or not, the colour and the way of draping or arranging it around the body. However, gender distinction was fundamental in ancient societies and certainly saw its expression in clothing in ancient Mesopotamia, in the way of arranging the garment around the body with the use of accessories.

Today, men and women do not button their shirts in the same way: men have the buttons on the right side, women on the left. The origin of this custom comes from the seventeenth century, as only women of the upper echelons of society used to wear complicated clothes with buttons and needed the help of their servants to get dressed: buttons on blouses for women were reversed to facilitate the task of their domestics who were facing them during dressing. Male costume was more simple, and men did not need 
help to get dressed. Poor women had simple clothes without buttons. So this apparent gendered distinction takes its origin in the social status of some women. In other traditions, the closing direction of a garment may have a completely different meaning. For example, the left side of the Japanese kimono and the yukata, which consists of a simplified kimono - is wrapped over the right side; it is closed the other way around when dressing a body for a funeral. The way we dress obeys a whole series of codes that are not necessarily related to the person's gender. Written documentation may allude to some of these codes which might be linked to the social status, the ethnicity, the milieu, the profession or the gender of a person. These might have an echo in archaeological discoveries but are not necessarily reflected in figurative representations that follow their own conventions.

\section{Acknowlegments}

A first version of this paper was given in Copenhagen on November 17, 2017, thanks to the joint invitation of the Centre for Textile Research and the Department of Cross-Cultural and Regional Studies. I wish to thank warmly Eva Andersson Strand, Nicole Brisch and Marie-Louise Nosch for the great honour they bestowed on me by inviting me on that specific day. The 'Textiles and Gender' conference was the concluding event of the International Research Network Ancient Textiles from the Orient to the Mediterranean and I wish to thank the CNRS which has generously contributed to the activities of this network between 2015 and 2018 .

\section{Notes}

i. (Le chercheur doit s'intéresser à) 'la tendance de toute couverture corporelle à s'insérer dans un système formel organisé, normatif, consacré par la société.'

ii. Translation from ETCSL 2.5.4.11. http://etcsl.orinst.ox.ac.uk/cgi-bin/etcsl.cgi?text=t.2.5.4.11\&charenc=j (accessed December 20, 2018). For perhaps a similar feature, see Volk 1989:150, L. 65-70 (lines attested already in the Old Babylonian version): 'I place right to left, I place left to right. I change man into woman, I change woman into man. I am the one who decorated a man into a woman. I am the one who decorated a woman into a man.' Streck and Wasserman 2018: 5-6, n. 8 provide further examples.

iii. The reference to publications and not directly to the artefacts must take into consideration the possible rightleft inversion of the photos of reproduced works.

iv. Michel 1997; Dercksen 1991; Demare-Lafont 2008; Michel 2020: no. 15. The word 'headscarf' is preferred to 'veil' here because this last word is too connoted and has important echoes for our contemporary society (van de Mieroop 1999: 138-60; Westenholz 1990).

v. TC 3, 202:15-16, 13 gín kù-babbar tù-dí-tám, a-na kà-li-tí-ni. Later texts from El Amarna and Alalah confirm that such jewels were offered as bridal gifts (see for example EA 25: iii 64).

vi. Similar clauses may be found for example at Nuzi; when a widow, who was also a 'mother', wanted to remarry after having inherited from her husband, she had to leave the house 'naked', thus giving up everything (see HSS $19,19)$.

vii. Toggle pins made in precious metals are also found in testaments found at Ekalte (WVDOG 102, 19:12; WVDOG 102, 95:12).

viii. Archaeological reports usually give the lengths of the pins while cuneiform texts provide their weight.

ix. This highlighting of the male belt is visible on representations from the fourth to the late first millennium BCE. For example, on the Uruk vase dating to the end of the fourth millennium BCE, a servant is holding in his hands the hanging part of the king-priest's belt; the servant himself wears a skirt attached with a long belt (Breniquet 2008: 163, fig. 47). 


\section{Bibliography}

Arkhipov, I. (2012), Le vocabulaire de la métallurgie et la nomenclature des objets en métal dans les textes de Mari, Archives Royales de Mari 32, Leuven: Peters.

Bahrani, Z. (2001), Women of Babylon. Gender and representation in Mesopotamia, New York: Routledge.

Barthes, R. (1957), 'Histoire et sociologie du vêtement. Quelques observations méthodologiques', Annales. Économie, Sociétés, Civilisations, 3: 430-41.

Breniquet, C. (2008), Essai sur le tissage en Mésopotamie des premières communautés sédentaires au milieu du IIIe millénaire avant J.-C., Travaux de la Maison René-Ginouvès 5, Paris: De Boccard.

Breniquet, C. (2013), 'Functions and Uses of Clothes in the Ancient Near East. Summary and Perspectives,' in M.-L. Nosch, H. Koefoed et E. Andersson Strand (eds), Textile Production and Consumption in the Ancient Near East. Archaeology, Epigraphy, Iconography, 1-25, Ancient Textiles Series 12, Oxford: Oxbow Books.

Cifarelli, M. (2017), 'Costly Choices: Signaling Theory and Dress in Period IVB Hasanlu, Iran', in M. Cifarelli and L. Gawlinski (eds.), What Shall I Say of Clothes Theoretical and Methodological Approaches to the Study of Dress in Antiquity, 101-19, Selected Papers on Ancient Art and Architecture 3, Boston: Archaeological Institute of America.

Collins, B. J. (1997), 'Hittite Canonical Compositions - Rituals: 'The First Soldiers'Oath (no. 1.66)', in W.W. Hallo et al. (eds), The Context of Scripture. Volume I: Canonical Compositions from the Biblical World, 165-7, Leiden: Brill.

Couturaud, B. (2019), Les incrustations en coquille de Mari (Subartu XL), Turnhout : Brepols.

Demare-Lafont, S. (2008), “'A cause des anges.' Le voile dans la culture juridique du Proche-Orient ancien', in O. Vernier, M. Bottin and Marc Ortolani (eds.), Études d'histoire du droit privé en souvenir de Maryse Carlin, 235-54, Paris : La Mémoire du Droit.

Dercksen, J. G. (1991), 'The Old Assyrian marriage contract AKT 1 77', Nouvelles Assyriologiques Brèves et Utilitaires, 1991: no. 28.

Dercksen, J. G. (2005), 'Adad is King! The Sargon Text from Kültepe (with an appendix on MARV 4, 138 and 140), Jaahrbericht Ex Orient Lux, 39: 107-29.

Durand, J.-M. (1998), Document épistolaires du palais de Mari, tome II, Littératures anciennes du Proche-Orient 17, Paris : Editions du Cerf.

Durand, J.-M. (2009), La nomenclature des habits et des textiles dans les textes de Mari, Archives Royales de Mari 30, Paris : CNRS éditions.

Foster, B. R. (2005), Before the Muses. An Anthology of Akkadian Literature ( $3^{\text {rd }}$ Edition), Bethesda: CDL Press.

George, A. R. (2003), The Babylonian Gilgamesh Epic; Introduction, Critical Edition and Cuneiform texts, vol. I, Oxford: Oxford University Press.

George, A. R. (2018), 'Enkidu and the Harlot: Another Fragment of Old Babylonian Gilgameš', Zeitschrift für Assyriologie, 108: 10-21.

Günbatt1, C. (1998), 'Kültepe'den Akadlı Sargon'a Ait Bir Tablet, Archivum Anatolicum, 3: 131-55.

Harlow, M. and Michel, C. (in press), 'Textiles from Mesopotamia to Greece ( $3^{\text {rd }}$ millennium BCE $-3^{\text {rd }}$ century CE)', in R. Mattila, S. Fink and S. Ito (eds), Evidence Combined: Western and Eastern Sources in Dialogue, Eleventh Symposium of the Melammu Project, Finnish Institute in the Middle East, 3-5 April 2017.

Hoss, S. (2012), 'The Roman Military Belt,' M.-L. Nosch (ed), Wearing the Cloak: Dressing the Soldier in Roman Times, 29-44, Ancient Textile Series 10, Oxford: Oxbow Books. 
Iamoni, M. (2012), ‘Toggle Pins of the Bronze Age: A Matter of Style, Function and Fashion?', in G. B. Lanfranchi, D. Morandi Bonacossi, C. Pappin and S. Ponchia (eds), Leggo! Studies Presented to Frederick Mario Fales on the Occasion of His $65^{\text {th }}$ Birthday, 349-63, Wiesbaden: Harrassowitz Verlag.

Klein, H. (1983), 'Tudittum', Zeitschrift für Assyriologie, 73: 255-84.

Kouwenberg, N. J. C. (2015), 'Sargon's tüdittum, or How to Make Fools of Your Enemies, in İ. Albayrak, H. Erol and M. Çayır (eds), Cahit Günbattı'ya Armağan/Studies in Honour of Cahit Günbattı, 165-70, Ankara: Ankara Üniversitesi.

Kouwenberg, N. J. C. (2017), A Grammar of Old Assyrian, Handbook of Oriental Studies 118, Leiden: Brill.

Kulakoğlu, F. and Kangal, S. (2010) Anadolu'nun Önsözü Kültepe Kaniş-Karumu. Asurlular Ístanbul'da, Kayseri: Kayseri Metropolitan Municipality.

Michel, C. (1997), 'Un témoignage paléo-assyrien en faveur du port du voile par la femme mariée', Nouvelles Assyriologiques Brèves et Utilitaires 1997, no. 40.

Michel, C. (2001), Correspondance des marchands de Kanish, Littératures anciennes du Proche-Orient 19, Paris: Editions du Cerf.

Michel, C. (2020), Women in Aššur and Kaneš from the private archives of Assyrian merchants of the early $2^{\text {nd }}$ millennium $B C E$, Writings from the Ancient World, Baltimore: Society for Biblical Literature.

Michel, C. (forthcoming), 'I will fix a toggle pin on your breast.' New data about toggle pins in the Old Assyrian period', in F. Kulakoğlu, C. Michel and G. Kryszat (eds), Cultural Exchanges at Kültepe and Surroundings from the $4^{\text {th }}$ to the $1^{\text {st }}$ Millennium BCE, Kültepe International Meetings 4, Subartu, Turnhout: Brepols.

Michel, C. and Veenhof, K. R. (2010), 'The Textiles traded by the Assyrians in Anatolia (19th-18th Centuries BC)', in C. Michel and M.-L. Nosch (eds), Textile Terminologies in the Ancient Near East and Mediterranean from the Third to the First millennia BC, 209-69, Ancient Textiles Series 8, Oxford: Oxbow Books.

Parrot, A. (1981), Sumer, L'Univers des formes (nouvelle édition), Paris : Editions Gallimard.

Rendu Loisel, A.-C. (in press), Nude Females and Girded Men. Clothes and Gender in the Akkadian Literature, in R. Mattila, S. Fink and S. Ito (eds), Evidence Combined: Western and Eastern Sources in Dialogue, Eleventh Symposium of the Melammu Project, Finnish Institute in the Middle East, 3-5 April 2017.

Roth, M. (1996), Law Collections from Mesopotamia and Asia Minor ( $2^{\text {nd }}$ edition), Writings from the Ancient World 6, Atlanta: Society for Biblical Literature.

Sasson, J. (2015), From the Mari Archives. An Anthology of Old Babylonian Letters, Winona Lake: Eisenbrauns.

Schmidt-Pantel, P. (2019), 'Der Gürtel, Körperschmuck, Statussymbol und Geschlechtsmerkmal', in B. Wagner-Hasel and M.-L. Nosch (eds), Gaben, Waren und Tribute. Stoffkreisläufe und antike Textilökonomie/ Don, marchandise et impôt. La circulation des biens textiles et l'économie antique / Gifts, Commodities and Dues. The Circulation of Textiles and Ancient Economy. 9-10 June, 2016. Leibniz Universität Hannover, 333-55, Hannovre: Steiner Verlag.

Spycket, A. (1981), La statuaire du Proche-Orient ancien, Handbuch der Orientalistik 2, Leiden: Brill.

Streck, M. P. and Wasserman, N. (2018), 'The Man is Like a Woman, the Maiden is a Young Man: A new edition of Ištar-Louvre (Tab. I-II)', Orientalia, 87: 1-38.

Tanaka, T. (2014), 'Dress and Identity in the Old Assyrian Sargon Legend', Kaskal, 11: 141-58.

Van de Mieroop, M. (1999) Cuneiform Texts and the Writing of History, Approaching the Ancient World, New York: Routledge. 
Volk, K. (1989), Die Balag-Komposition Uru am-mair-ra-bi, Freiburger Altorientalische Studien 18, Stuttgart: Franz Steiner Verlag.

Westenholz, J. G. (1990), 'Toward a new conceptualization of the Female role in Mesopotamian society', Journal of the American Oriental Society, 110: 510-21. 